\title{
Delineation of Holocene-Pleistocene aquifer system in parts of Middle Ganga Plain, Bihar, Eastern India through DC resistivity survey
}

\author{
Shuva Shankha Ganguli • Shashikant Singh
}

Received: 19 January 2014/ Accepted: 1 July 2014/Published online: 27 July 2014

(C) The Author(s) 2014. This article is published with open access at Springerlink.com

\begin{abstract}
The study area forms a part of the Middle Ganga Plain (MGP) and experiences intensive groundwater draft due to domestic, irrigation and industrial purposes. Geoelectrical surveys were carried out in a geomorphic unit of MGP called South Ganga Plain, along the northsouth traverse covering a total $50 \mathrm{~km}$ stretch. Interpreted results of the total of 17 vertical electrical soundings, carried out, provided information on aquifer and aquitard geometry and sediment nature in different aquifer systems. Bedrock topography is also demarcated along the northsouth transect. The estimated dip of massive bedrock is less than $0.5^{\circ}$ and dips toward north. The survey results show that a two-tier aquifer system exists in Newer alluvium parts of the study area and it is replaced by a single aquifer system at Older alluvium that occurs under thick clay/ sandy clay bed in the southern part. An exponential decay of the aquifer potential is observed from north to south. Paleo channel Sone River is traced and it forms a potential aquifer.
\end{abstract}

Keywords South Ganga Plain (SGP) - Geoelectrical survey $\cdot$ Aquifer geometry $\cdot$ Newer alluvium · Older alluvium · Bedrock topography

\footnotetext{
S. S. Ganguli $(\square)$

Geophysics Division, Geological Survey of India Southern

Region, Hyderabad 500068, India

e-mail: shuvaganguli@gmail.com

S. Singh

Central Ground Water Board, Northern Region, Bhujal Bhawan,

Sector-B, Sitapur Road Yojana, Lucknow 226021, India

e-mail: singhskbhu@gmail.com
}

\section{Introduction}

The Gangetic Plains of India are intensively populated ( $\sim 250$ million) and irrigation has always been central to life and society in general. Agricultural activities were traced even 2000 years ago and suggests that water-managed agriculture has played a key role in the evolution of civilization in this part of the world.

The shallow aquifers $(\sim 50 \mathrm{~m})$ in the Gangetic alluvial deposits hold $30 \%$ of the total replenishable groundwater resources of India (Govt of India 2006). The unit experiences intensive groundwater draft and remains as a major input for societal development. Rapid growth of privately owned hand pumps $(\sim 50,000$ presently $)$ has been registered (45\% from 1994 to 2001 in Patna district) during the last decade within the entire stretch of the study area, covering two densely populated districts of the state, namely Patna, the capital of the state Bihar, and Jehanabad (Govt of Bihar 2001).

Central Ground Water Board (CGWB), Ministry of Water Resources, Govt of India, has carried out exploratory drilling within $10 \mathrm{~km}$ of the southern stretch of Ganga River in Patna urban area. However, a small amount of documented (published) information is available on aquifer geometry and the nature of the alluvial tract in the southern part of the east-west flowing Ganga River and the eastern part of the northerly flowing Sone River, in Bihar state. The irrigation and domestic demand for water are mostly catered through groundwater for the entire stretch of the study area. Abstraction structures are mainly shallow hand pumps. A very a small amount of borehole information is available, particularly along the stretch under study. Hence, a geoelectrical (DC resistivity) survey was conducted along a traverse from the outskirts of Patna urban area in newer 
alluvium to bordering south Bihar highlands covered by older alluvium.

Geoelectrical technique, especially direct current (DC) resistivity survey (Telford et al. 1990), is a widely used technique for hydrogeological investigation (Zohdy et al. 1990; Parasnis 1997), since resistivity is strongly related to different grain size of the sediment in freshwater aquifers. The saturated clay acts as a good conductor and progressively the coarser sediments behave as poor conductors. Resistivity data can thus be correlated with subsurface lithology. Geoelectrical surveys are used to deal with various groundwater issues like identification of fresh-salt water interface (Flathe 1967), determination of aquifer yield potential, identification of buried stream channels (Zohdy and Jacson 1969; Zohdy et al. 1990), delineation of fracture zones in hard rock terrain (Yadav and Singh 2007) and arsenic contamination in groundwater (Chandra et al. 2011). The primary advantage of this technique is that it is economical and noninvasive.

For the present study vertical electrical soundings (VES) were carried out using Schlumberger configuration (Telford et al. 1990). The primary objective of VES is to measure subsurface variation of resistivity with depth at a particular point. In VES, the apparent resistivity is measured for each current electrode separation and the current electrode separation is increased successively to facilitate deeper depth of exploration. The measured apparent resistivity data, with corresponding current electrode separation, is then interpreted in terms of geoelectrical parameters (i.e., resistivity and thickness). The geoelectrical parameters are correlated with a different lithological formations, which provides a vivid description of the subsurface lithology and aquifer disposition characteristics.

For the present study, 17 VES were carried out along a north-south transect at the study area along with hydrogeological investigations. The study aims to (a) delineate the geometry of different aquifer systems down to $250 \mathrm{~m}$ in the newer alluvial belt and adjoining stretch of older alluvium of the aquifer systems and to mark the boundary of Holocene and Pleistocene aquifers, (b) delineate bedrock topography along the traverse, (c) tectonic control over the aquifer regime in the study area.

\section{Study area setting}

The study area (Fig. 1b, c) forms a traverse of the South Ganga Plain (SGP), a major geomorphic unit of the Middle Ganga Plain (MGP) for about $51 \mathrm{~km}$ length, stretched in the north-south direction through Patna and Jehanabad districts. A major structural high Munger-Saharsa ridge (Fig. 1d) forms the south-western boundary of the study area while north-south aligned Sone River and east-west aligned Ganga River form the eastern and northern boundaries, respectively. The area represents a northerly wedge of Quaternary deposit lying unconformably over the Precambrian bedrock. The study region represents a monotonously flat terrain and exhibits a gentle slope toward north having elevation 52-67 $\mathrm{m}$ above mean sea level (msl). The northern part of the region is flood prone, being located in the interfluves region of two perennial rivers: the Ganga and the Sone (Fig. 1d). Other prominent rivers are Punpun, Morhar and Dharda rivers. All are ephemeral in nature. The fluvial regimes of the area are largely controlled by climatic and tectonic evolution in Quaternary. The area is traversed by one major subsurface fault (East Patna Fault, EPF) trending in the NW-SE direction.

A warm and humid climate embraces the area. The summer (March-June) is hot with a mean maximum temperature during June (peak summer) at $36.6^{\circ} \mathrm{C}$. The dry and cold winter (October-February) records a mean minimum temperature of $9.2^{\circ} \mathrm{C}$ in January. The humidity varies from 24.7 to $83.45 \%$ (Govt of Bihar 1994). The average annual (20 years) rainfall is $1,061 \mathrm{~mm}, 88 \%$ of which is controlled by the south-west monsoon (JuneSeptember). The population density of the area varies from 963 person $/ \mathrm{km}^{2}$ (Jehanabad) to 1,132 person $/ \mathrm{km}^{2}$ (Patna) (Govt of India 2001). The region represents an agrarian economy with a cropping intensity of $\sim 130 \%$. Paddy is the main crop grown during monsoon, while wheat and pulses are cropped in winter. Groundwater caters to the entire domestic need and more than $80 \%$ of the irrigation requirement (Govt of India 2006) of the state.

\section{Geology and hydrogeology}

The entire Gangetic plain is classified in three subunits: 1 . Upper Ganga Plain (UGP), 2. Middle Ganga Plain (MGP), 3. Lower Ganga Plain (LGP) (Sinha et al. 2005). The alluvial deposits of Bihar in Eastern India, covers over $\sim 90 \%$ of the geographical area $\left(\sim 94,000 \mathrm{~km}^{2}\right)$ of the state and is located in the central part of the east-west running Ganga basin, referred to as Middle Ganga Plain. The MGP is an active depositional basin and forms one of the important repositories of Quaternary sediments in India. The sedimentation, geomorphology and tectonics of this unit are well studied and documented (Sastri et al. 1971; Rao 1973; Singh 2004; Acharya 2005; Sinha et al. 2005). The unconsolidated sand layers within the top $250 \mathrm{~m}$ of the thick Quaternary sequence form potential aquifers, which are exploited to meet the entire domestic and industrial needs and a major portion of irrigation demand, yet quantification of the Quaternary aquifers especially in the eastern part of Sone River, South Ganga 


\section{STUDY AREA IN SOUTH GANGA PLAIN}
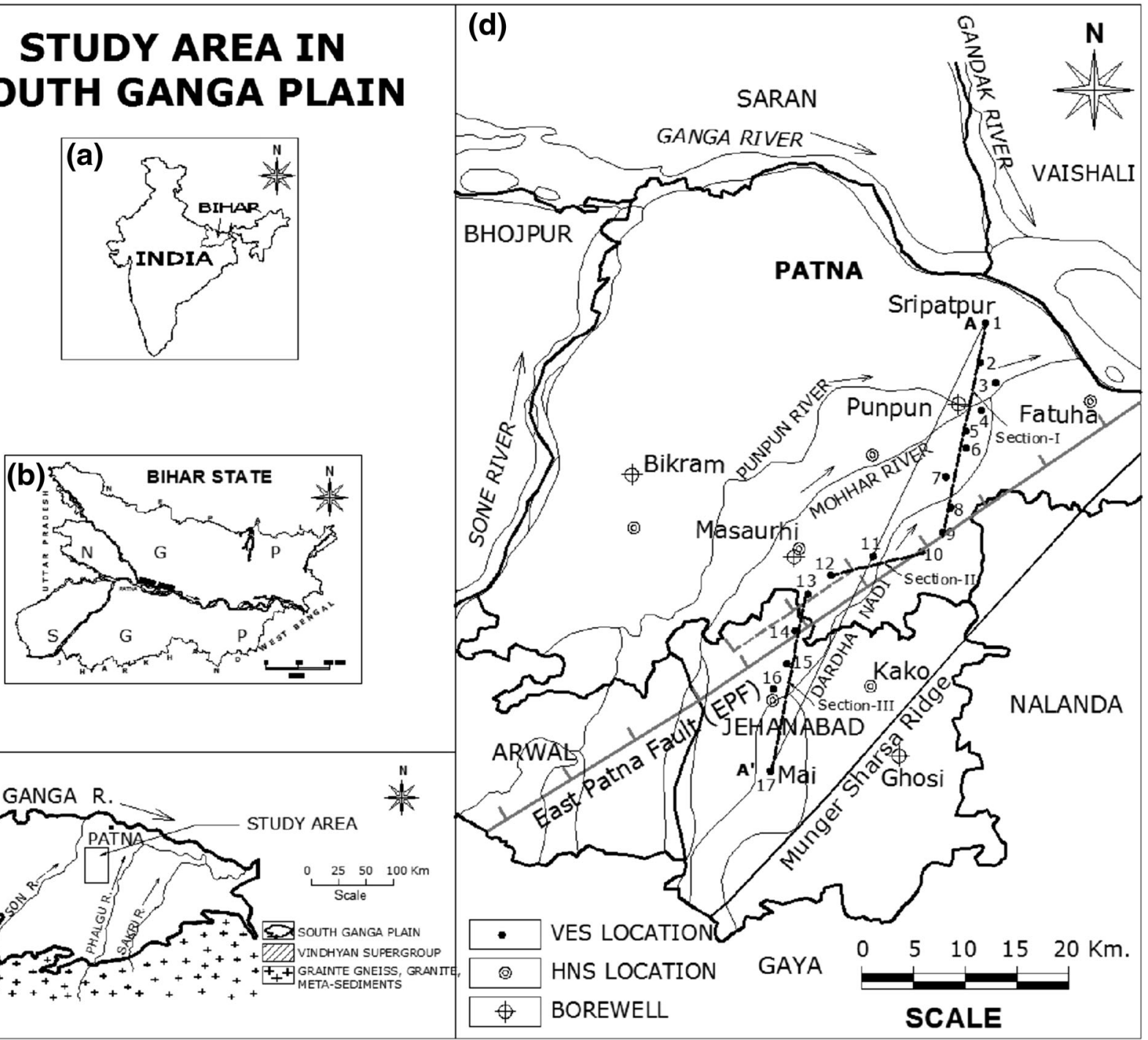

Fig. 1 Map of the study area. a. Location of Bihar in India. b. Location of South Ganga Plain (SGP) in Bihar state. c. Study area in the backdrop of the geological map of parts of South Ganga Plain.

d Important tectonic features (compiled from Sahu et al. 2010), river, well location, HNS Hydrograph Networking Station, VES location along with the numbers in the study area

Plain has received less attention. CGWB has carried out district-level hydrogeological surveys aided by exploratory drilling in the arsenic-affected areas (CGWB and PHED 2005) of Bhojpur District (Fig. 1d). The shallow aquifer in the newer alluvium of Bhohpur District is reported to be arsenic contaminated (Sahu et al. 2010). Aquifer geometry and hydraulic properties in the older alluvium further east of the study area, in Nalanda District, were also studied (Raja et al.2003; Saha et al. 2007; 2009a, b).The Quaternary deposits in South Ganga Plain (SGP) lie unconformably over the northerly sloping bedrock and are not influenced by marine transgression (Tandon et al. 2008). Seismic refraction study (Bose et al. 1976) has established that the thickness of the sediments varies from few meters near the Precambrian exposures to $\sim 700 \mathrm{~m}$ near the
Punpun-Ganga confluence. The Quaternary sequence of the MGP is conveniently subdivided into older alluvium (Pleistocene age) and newer alluvium deposits of Holocene age (Acharya 2005). Alluvial deposits of the Sone Ganga interfluve region of SGP is divided into three morphostratigraphic units on the basis of occupational level of the basin, characteristics of sediments and nature of paleosols (Chakraborty and Chattopadhyay 2001). The lower part (older alluvium) marked by sand, silt and clay is assigned to the Pleistocene age. The upper segment (newer alluvium) is divided into Belhar and Diara formations and assigned to the Holocene age (Saha et al. 2010). The younger unit covers a 10 - to $25-\mathrm{km}$ wide stretch along the Ganga, is characteristically unoxidized and consists of sediments deposited in a fluvial and fluvio-lacustrine setup 
Table 1 Assembly design and aquifer parameters of the borewell at Bikram and Jehanabad

\begin{tabular}{|c|c|c|c|c|c|c|}
\hline Location & $\begin{array}{l}\text { Depth Drilled } \\
\text { (m bgl) }\end{array}$ & $\begin{array}{l}\text { Granular zone } \\
\text { tapped (m) }\end{array}$ & $\begin{array}{l}\text { Static Water } \\
\text { Level (m bgl) }\end{array}$ & $\begin{array}{l}\text { Discharge } \\
\left(\mathrm{m}^{3} / \mathrm{h}\right)\end{array}$ & $\begin{array}{l}\text { Drawdown } \\
\text { (m) }\end{array}$ & $\begin{array}{l}\text { Transmissivity } \\
\left(\mathrm{m}^{2} / \text { day }\right)\end{array}$ \\
\hline Bikram & 240 & $\begin{array}{c}40-48 \\
54-60 \\
66-74 \\
124-128 \\
134-142 \\
145-159\end{array}$ & 2.73 & 535.2 & 4.4 & 19,540 \\
\hline Jehanabad & 147 & $\begin{array}{l}113-125 \\
129-140\end{array}$ & 4.57 & 76.78 & 9.44 & 120.82 \\
\hline
\end{tabular}

(Singh 2004) marked as Holocene sediments. The Holocene newer alluvium surface was recognized by gray- to black-colored organic-rich argillaceous sediments in entrenched channels and floodplains of Ganga River, while the Pleistocene older alluvium surface was recognized by yellow-brown colored sediments with profuse calcareous and ferruginous concretions. A $25-$ to $35-\mathrm{km}$ southern stretch along the east-west flowing Ganga River is marked as the boundary of newer alluvium (Saha et al. 2010, Acharya 2005).

Sone River has undergone avulsion several (9) times, in the recent geological past $(<10,000$ years $)$ and its abandoned channels mostly lie within $\sim 50 \mathrm{~km}$ east from the present channel course (Sahu et al. 2010). The oldest bed of Sone River almost coincides with the north-south aligned geological section discussed in the present study. The above discussions suggest the fact that sediment deposited by Sone River is in the form of active channel deposit of coarse grain nature. The channel avulsion of Sone is primarily controlled by tectonic activity of the area (Sahu et al. 2010).

One exploratory drilling was conducted By CGWB at the southern part of the study area, at Jehanabad (Fig. 1d) and its details are given in Table 1. The litholog of another borewell at Ghosi (Fig. 2a) prepared from visual analysis drill-cut samples is presented in Fig. 2a. The depth of the borewell was $135 \mathrm{~m}$ bgl. Litholog indicates an alteration of clay, sand (fine to coarse), sandy clay and silt up to $135 \mathrm{~m}$ below the ground level (bgl). At the top a 12-m clayey formation is followed by a coarse sand bed up to a depth of $26 \mathrm{~m}$ representing a temporary high-energy condition. A thick clay bed $(75 \mathrm{~m})$ underlies and is followed by a sand sequence up to a depth of $135 \mathrm{~m}$.

The geophysical log of a borewell at Bikram is also presented in Fig. 2b. Self-potential (SP) along with resistivity (Telford et al. 1990) of the formations encountered in the borewell, were recorded using SP and normal logs (i:e $\mathrm{N}-16^{\prime \prime}$, short normal and N-64", long normal). The electrical $\log$ data were interpreted in terms of lithological parameters in consultation with drill-cut samples. Details of the well are presented in Table 1. The log shows that thick coarse sand bed continues from $30 \mathrm{~m}$ below ground level till the appearance of a clay bed at $75 \mathrm{~m}$ depth. There are other sets of clay bed occurring at 95-m (10-m thick) and 115-m depth separated by fine sand layers. The coarse sand bed is deposited by Sone River during the shifting of river course from east to west in the recent geological past and represents high energy conditions. The second aquifer comprising fine to medium sand continues up to a depth of $230 \mathrm{~m}$ till the appearance of another clay bed. The log broadly reveals a two-tier aquifer system up to a depth of $230 \mathrm{~m} \mathrm{bgl} \mathrm{separated} \mathrm{by} \mathrm{sets} \mathrm{of} \mathrm{clay} \mathrm{bed.} \mathrm{The} \mathrm{first} \mathrm{one} \mathrm{from}$ 20- to 75-m depth was formed by coarse sand and another one from 115 - to $230-\mathrm{m}$ depth was formed by fine to medium sand.

The same type of aquifer system persists in the western part of Sone River, in Bhojpur District. A clay bed ( 25-m thick) separating the Holocene and Pleistocene aquifer is delineated (Saha et al. 2010). The clay bed vertically separates the aquifer system; the shallow aquifer occurring above the clay bed is assigned to the Holocene age and the aquifer occurring below this clay bed is marked as a Pleistocene aquifer. The same study shows this clay bed to be laterally extensive in the east-west direction across Sone River.

Seasonal water level behavior of the dug wells distributed over newer and older alluvium of the study area was studied from the year 2000 to 2010 and presented in Table 2. The average pre-monsoon water level varies from $3.44 \mathrm{~m}$ below ground level (bgl) to $7.10 \mathrm{~m} \mathrm{bgl}$ in the newer alluvium area, while for the older alluvium it ranges from 4.31 to $4.55 \mathrm{~m} \mathrm{bgl}$ and for the post-monsoon period average variation is 2 to $6.61 \mathrm{~m} \mathrm{bgl}$ and 3.18 to 3.47 for newer and older alluvium, respectively. The depth to water level in the newer alluvium is greater compared to older alluvium for both the pre- and post-monsoon periods. The water level data from two representative wells from newer and older alluvium are presented in Fig. 3a, b. The second well is in Jehanabad township area (Fig. 2a) and shows a 


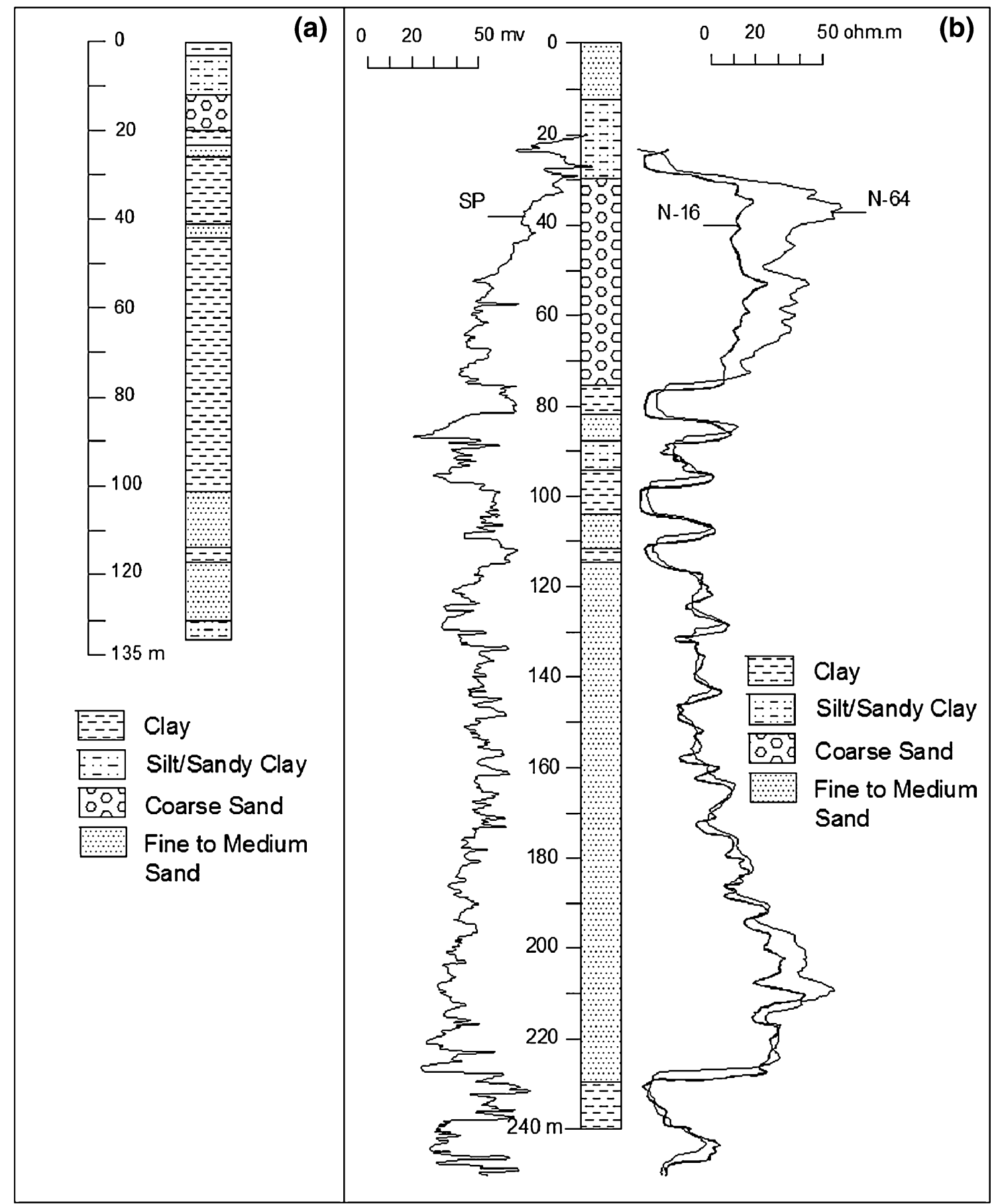

Fig. 2 Litholog and geophysical log at (a) Ghosi, pre-monsoon water level $6.5 \mathrm{~m}$ bgl, post-monsoon water level $2.5 \mathrm{~m} \mathrm{bgl}$; (b) Bikram, premonsoon water level $4.6 \mathrm{~m}$, post-monsoon water level $2.6 \mathrm{~m}$ bgl. $N$ 16 represents short normal resistivity $\log , \mathrm{N}-64$ represents long

declining trend for both the pre- and post-monsoon period. The seasonal behavior of water level in SGP strongly indicates that monsoon rainfall plays an important role in normal resistivity log and $S P$ represents self-potential log. N-64 log brings radially (borewell as the center) deeper resistivity information depth than N-16. $b g l$ below ground level

shallow aquifer recharge. The general groundwater flow direction in the study area is in NE to NNE, indicating the gaining nature of the Ganga River. 
Table 2 Water level data from the study region

\begin{tabular}{llllll}
\hline Place & $\begin{array}{l}\text { Pre- } \\
\text { monsoon } \\
(\mathrm{m} \mathrm{bgl})\end{array}$ & $\begin{array}{l}\text { Average } \\
(\mathrm{m})\end{array}$ & $\begin{array}{l}\text { Post- } \\
\text { monsoon } \\
(\mathrm{m} \text { bgl })\end{array}$ & $\begin{array}{l}\text { Average } \\
(\mathrm{m})\end{array}$ & $\begin{array}{l}\text { Fluctuation } \\
(\mathrm{m})\end{array}$ \\
\hline $\begin{array}{l}\text { Newer } \\
\text { alluvium }\end{array}$ & $3.44-7.10$ & 5.75 & $2.0-6.61$ & 4.67 & 1.08 \\
$\begin{array}{l}\text { Older } \\
\text { alluvium }\end{array}$ & $4.31-4.55$ & 4.43 & $3.18-3.47$ & 3.32 & 1.11 \\
\hline
\end{tabular}

\section{Geophysical survey}

A total of 17 VES with Schlumberger configuration were carried out for the present study (Fig. 1d). The VES were carried out with SYSCAL R2 resistivity meter which uses $12 \mathrm{v}$ car battery with a transformer as current injecting source. The maximum current electrode separation $(\mathrm{AB})$ for the VES ranged from 500 to $1800 \mathrm{~m}$. The potential electrodes' separation was (MN) increased accordingly, i.e., from 1 to $80 \mathrm{~m}$ so that the measured voltage never fell below 5 units. A minimum of five stacks (current was injected into the ground five times and its responses were added and averaged out for the particular measurement) were taken for each measurement, keeping signal to noise ratio zero. A preliminary appraisal of the VES curves has provided a good insight into the hydrogeological conditions of the study area. A good look at the shape of the sounding curve and ranges of the apparent resistivity values enable dividing the curves into groups. Each group represents a specific geologic or hydrogeological condition.

(a)

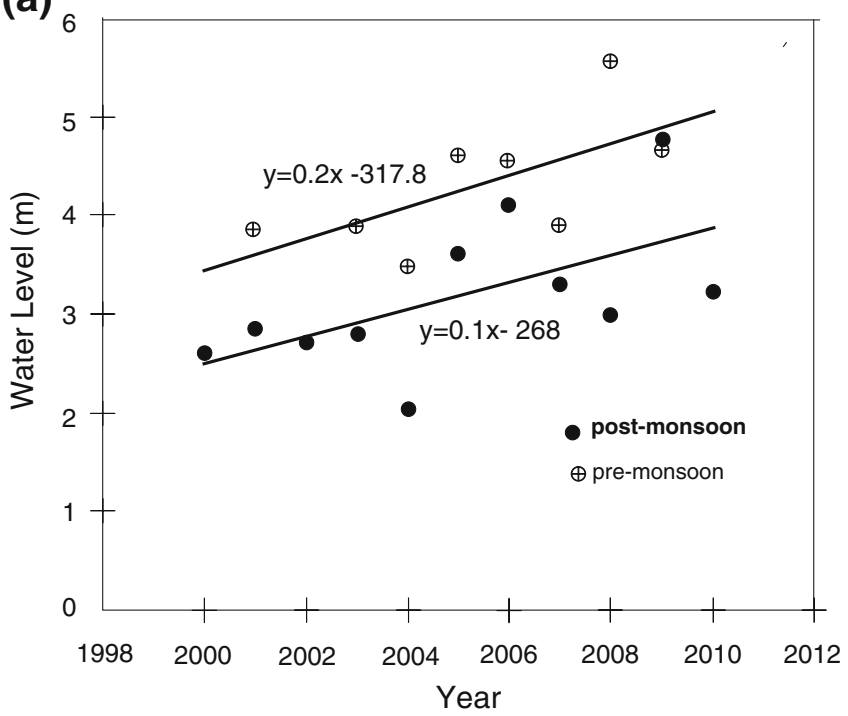

The VES curves of the entire transect can be classified into three groups (Fig. 1d):

(1) section I: Sripatpur to Abdhara (VES-1 to VES-9);

(2) section II: Dhanarua to Masauri (VES-10 to VES-13);

(3) section III: Gopalpur Mathia to Mai (VES-14 toVES17).

Section I: Sripatpur to Abdhara

The profile extends from Sripatpur (VES-1) in the north to Abdhara (VES-9) in the south. In general, curve types are (Fig. 4) AK/HK $\left(\rho_{1}<\rho_{2}<\rho_{3}>\rho_{4 /} \rho_{1}>\rho_{2}<\rho_{3}>\rho_{4}\right)$. Apparent resistivities values up to $\mathrm{AB} / 2=20$ remain within $10 \Omega \mathrm{m}$ indicating finer sediments at shallower depth. There is a steep increase in resistivity values $(\sim 10-50 \Omega \mathrm{m})$ for $\mathrm{AB} / 2 \sim 10-110 \mathrm{~m}$ indicating the coarse grain nature of the sediments. The resistivity values then show decreasing trend for larger $\mathrm{AB} / 2(>110 \mathrm{~m})$ indicating the medium grain nature of the sediments at deeper depth. VES-4 conducted at Abgila (VES-5) has maximum halfcurrent electrode spacing $(\mathrm{AB} / 2)$ of $900 \mathrm{~m}$ for estimating the basement depth at this particular survey point. However, the curve does not show any increasing trend for larger electrode spacing.

\section{Section II: Dhanarua to Masauri}

VES conducted at Masauri (VES-10), Chanaki (VES-11) and Dhanarua (VES-12) represents Section II. VES curves show (Fig. 5) HKH trend, but VES-12 is not in phase with the rest, indicating that the disposition sequence is the (b)

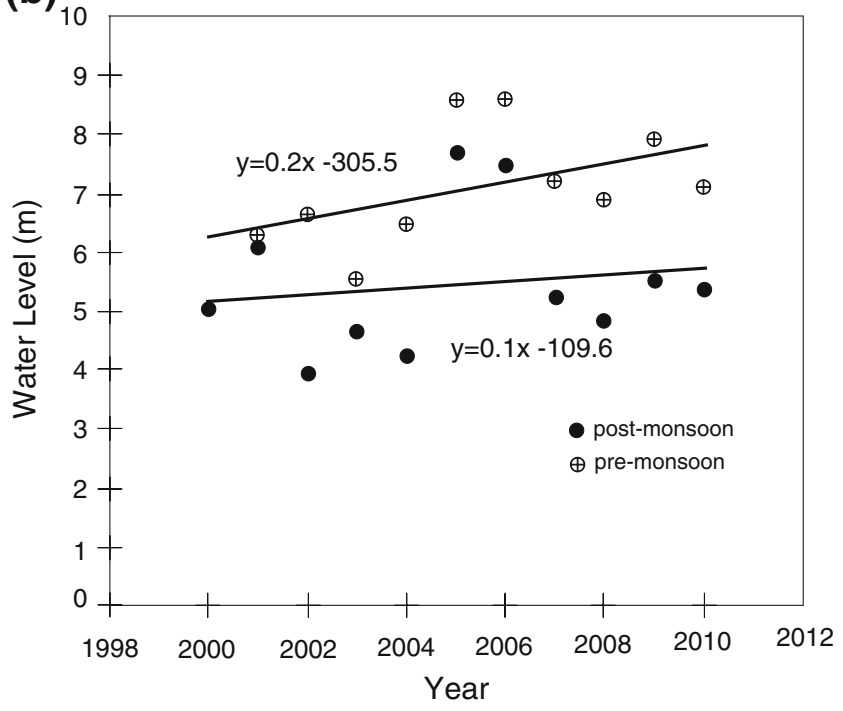

Fig. 3 Pre- and post-monsoon water level behavior, 2000-2010, location (a) Jehanabad and (b) Punpun 


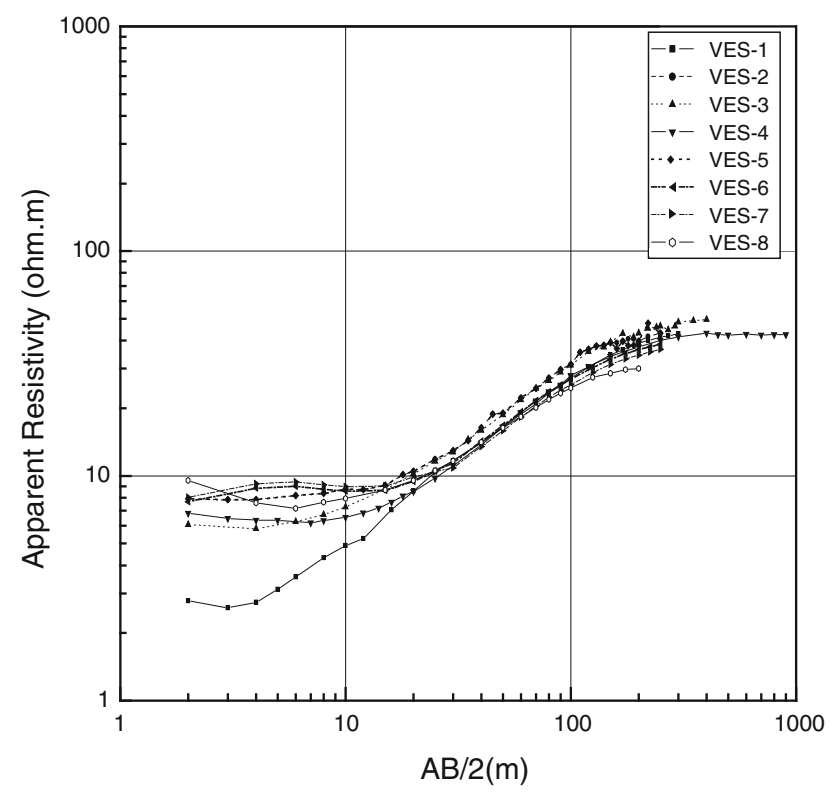

Fig. 4 VES curves along Section I (see Fig. 1d for VES locations)

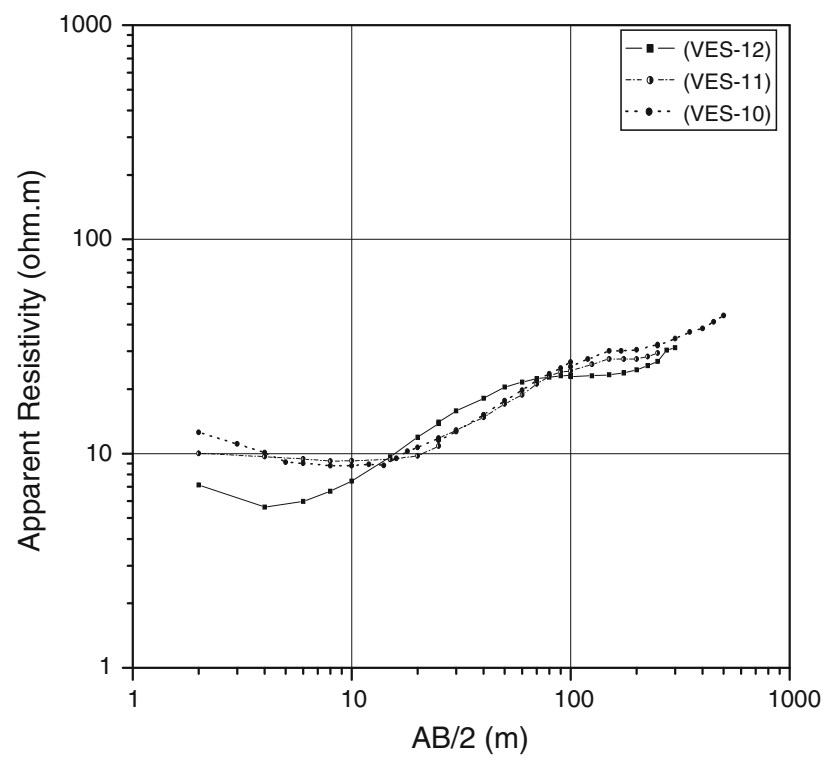

Fig. 5 VES curves along Section II (see Fig. 1d for VES locations)

same, but the depth to the lithological boundaries is different.

Steeply rising apparent resistivity values of VES-12 for larger electrode spacing $(\mathrm{AB} / 2>250 \mathrm{~m})$ indicates the appearance of bedrock.

\section{Section III: Gopalpur Mathai to Mai}

The VES curves along this section represents (Fig. 6) AA or HA type of curves except VES-13 which represents KH

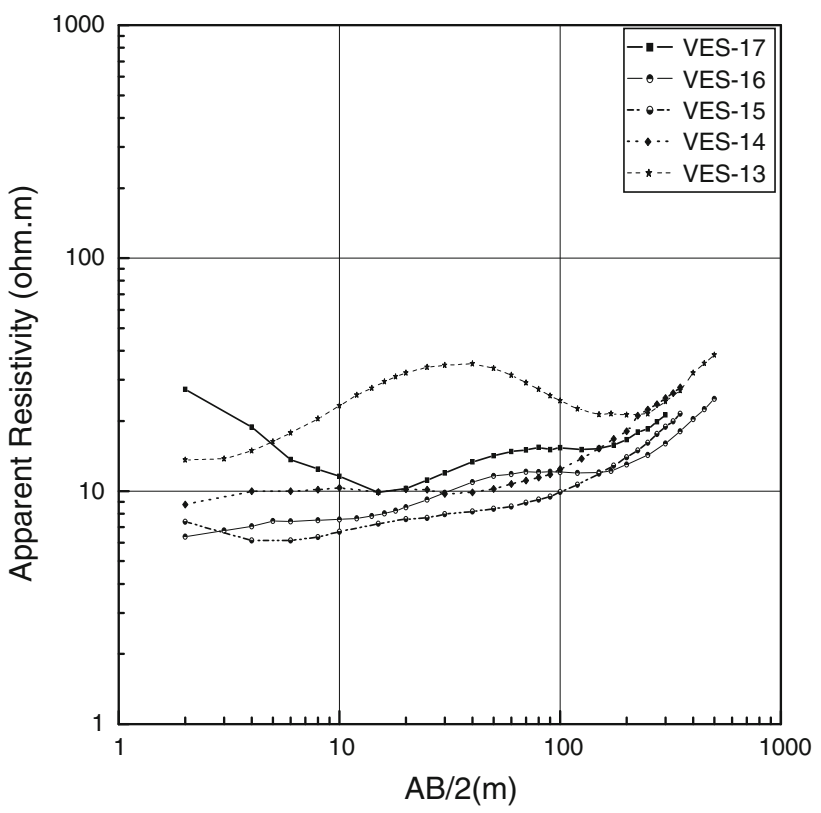

Fig. 6 VES curves along Section III (see Fig. 1d for VES locations)

type of curve, indicating a discontinuity in the horizontal lithological sequence from south to north.

The apparent resistivity curves were interpreted manually using a two-layer master curve and auxiliary curve (Bhattacharya and Patra 1968). Sincere effort was made to derive a model with minimum layer parameters, since with increasing number of layer parameters profile interpretation becomes very confusing. Manually interpreted curves are also interpreted through computer software IPI2Win (Bobachev 2003). The manually derived parameters are used as initial guess model and the final model parameters are accepted after inverting the data through the software keeping the RMS error limit $<2 \%$.

The quantitative interpretation of the VES curves is hampered by the well-known principle of equivalence, which means that different resistivity models can generate practically the same apparent resistivity curve. To select a model which best represents the hydrogeological conditions of the area; one needs to have the support of borehole litholog information. Two sets of borehole information were available for the present study and were used for calibrating the resistivity model.

Keeping the above-mentioned discussion in view, layered interpretation of all the curves was executed and the derived layer parameters are given in the following Table 3. In consultation with the geophysical log at Bikram and litholog of the borewell at Ghosi, the resistivity range of different lithological units is established and presented in Table 4. 
Table 3 Interpreted resistivity layer parameters

\begin{tabular}{|c|c|c|c|c|c|c|c|c|c|c|c|c|c|c|}
\hline \multirow[t]{2}{*}{ VES place } & \multicolumn{2}{|c|}{ 1st layer } & \multicolumn{2}{|c|}{ 2nd layer } & \multicolumn{2}{|c|}{ 3rd layer } & \multicolumn{2}{|c|}{ 4th layer } & \multicolumn{2}{|c|}{ 5th layer } & \multicolumn{2}{|c|}{ 6th layer } & \multicolumn{2}{|c|}{7 th layer } \\
\hline & $\rho_{1}$ & $h_{1}$ & $\rho_{2}$ & $h_{2}$ & $\rho_{3}$ & $h_{3}$ & $\rho_{4}$ & $h_{4}$ & $\rho_{5}$ & $h_{5}$ & $\rho_{6}$ & $h_{6}$ & $\rho_{7}$ & $h_{7}$ \\
\hline VES-1 Sripatpur & 3.4 & 1.0 & 1.0 & 1.0 & 9.5 & 10.0 & 65 & 90.5 & 46 & - & & & & \\
\hline VES-2 Fatehpur & 15.0 & 1.2 & 6.0 & 2.3 & 10 & 18.4 & 74.0 & 85 & 30 & - & & & & \\
\hline VES-3 Ajimchawk & 7.4 & 12.3 & 17.0 & 11.0 & 82.0 & 82.5 & 23.0 & - & - & - & & & & \\
\hline VES-4 Gaurichawk & 5.0 & 6 & 11.0 & 15.0 & 56.0 & 12.0 & 83.0 & 71 & 45 & - & - & - & - & - \\
\hline VES-5 Abgilla & 7.0 & 1.2 & 6.0 & 10.0 & 15.0 & 10.3 & 80.0 & 65.0 & 41.0 & - & & & & \\
\hline VES-6 Sapahaun & 6.6 & 2.8 & 6.3 & 13.0 & 86.0 & 69.5 & 46.0 & - & & & & & & \\
\hline VES-7 Oriyara & 6.5 & 1.0 & 12.0 & 1.5 & 7.0 & 15.0 & 78.0 & 15.0 & 28.0 & 49.0 & & & & \\
\hline VES-8 Sevdaha & 6.7 & 1.1 & 16.0 & 0.8 & 8.0 & 20.0 & 78.0 & 56.0 & 34 & - & & - & & \\
\hline VES-9 Abdhara & 11.1 & 1.3 & 4.3 & 1.2 & 8.6 & 16.5 & 60.0 & 50.0 & 15.0 & 48.0 & 45.0 & - & & \\
\hline VES-10 Dhanarua & 14.0 & 1.2 & 8.0 & 15.2 & 55.0 & 69.0 & 15.0 & 53.0 & 38.0 & 110 & 249 & HR & & \\
\hline VES-11 Chanaki & 6.5 & 3.8 & 8.0 & 13.4 & 63.0 & 46.0 & 34.0 & - & - & - & & & & \\
\hline VES-12 Masauri & 13.0 & 1.2 & 7.4 & 15.0 & 57.0 & 59.0 & 13.0 & 65.0 & 44.0 & 88.6 & 229.0 & HR & & \\
\hline VES-13 G-Mathai & 13.0 & 3.4 & 48.0 & 26.0 & 13.0 & 43.0 & 20.0 & 169.0 & HR & - & & & & \\
\hline VES-14 Sewanan & 7.5 & 1.0 & 12.2 & 1.4 & 10.0 & 67.0 & 32.0 & 67.0 & HR & - & & & & \\
\hline VES-15 Chamanbigha & 8.9 & 1.0 & 5.0 & 3.0 & 8.2 & 71.0 & 23.0 & 107 & HR & & & & & \\
\hline VES-16 Tuinibigha & 6.0 & 2.0 & 8.5 & 3.0 & 6.0 & 9.0 & 33.0 & 11.5 & 8.0 & 80.0 & 21.0 & 90.0 & HR & - \\
\hline VES-17 Mai & 33 & 1.5 & 12 & 5.6 & 5.0 & 6.2 & 42 & 13.0 & 10 & 87.5 & 30 & 42 & HR & - \\
\hline
\end{tabular}

$\rho_{\mathrm{i}}$ Resistivity values in $\Omega \mathrm{m}, h_{i}$ thickness in $\mathrm{m}, H R$ high resistivity

Table 4 Resistivity range for different lithological units

\begin{tabular}{ll}
\hline Resistivity $(\Omega \mathrm{m})$ & Lithology \\
\hline$<15$ & Clay/silt/sandy clay \\
$15-50$ & Fine to medium sand \\
$50-100$ & Coarse sand \\
$>500$ & Massive bedrock \\
\hline
\end{tabular}

\section{Discussion}

At Abgila (Fig. 1d), VES was conducted with the maximum current electrode spacing $(\mathrm{AB})$ of $1,800 \mathrm{~m}$ with the intention of estimating basement depth, but even with the mentioned maximum current electrode separation the apparent resistivity curve did not show any rising trend for larger electrode spacing and therefore any signature of massive bedrock (Fig. 7). Here, estimation of minimum depth to the bedrock was attempted. The VES was conducted with a maximum half-current electrode spacing $(\mathrm{AB} / 2) 900 \mathrm{~m}$. Another few points of apparent resistivity values from $\mathrm{AB} / 21000$ to $2000 \mathrm{~m}$ were added to the curve in such a fashion that apparent resistivity values increases in a linear fashion with $45^{\circ}$ slope. From this extended apparent resistivity (sounding) curve, the geoelectrical model was interpreted in such a fashion that the modelgenerated curve remained the same as the field curve up to $\mathrm{AB} / 2$ of 900 .
The original field curve and generated curve along with the layer parameters estimated in both the cases are presented in Table 5 for comparison. The model parameters in both the curves remain almost the same for the first three layers, but the model parameters change in the subsequent layer. The thickness of the fourth layer is $112.0 \mathrm{~m}$ from the generated curve with the resistivity value remaining almost the same. From the generated curve, the thickness of the fifth layer is $512 \mathrm{~m}$ and basement depth is $647 \mathrm{~m} \mathrm{bgl}$. Although some argument may be made about the model parameters estimated from the generated curve, the basement depth estimated is fair enough.

A north-south aligned geological section (A-A'), passing through newer and older alluvium, was derived on the basis of resistivity layer parameters (Fig. 8). The section reveals $\sim 15$ - to 25 -m thick clay/sandy clay bed present at the top of the aquifer system from extreme north of the profile to Gopalpur Mathia at the south and probably indicating the spatial boundary of newer and older alluvium (Sahu et al. 2010). Below the first clay/sandy clay unit, coarse sand bed (depth ranges from 30 to $105 \mathrm{~m}$, south to north) occurs from the extreme north up to Gopalpur Mathia and further south the coarse sand bed is absent. The geophysical log at Bikarm reveals the occurrence of three clay units, of thickness ranging from 5 to $10 \mathrm{~m}$, at 75 to $115 \mathrm{~m}$ of depth and separated by medium sand. The clay unit occurring at $95-\mathrm{m}$ depth is the most prominent one $(10-\mathrm{m}$ thick). The eastern extension of this clay bed is demarcated 
(a)

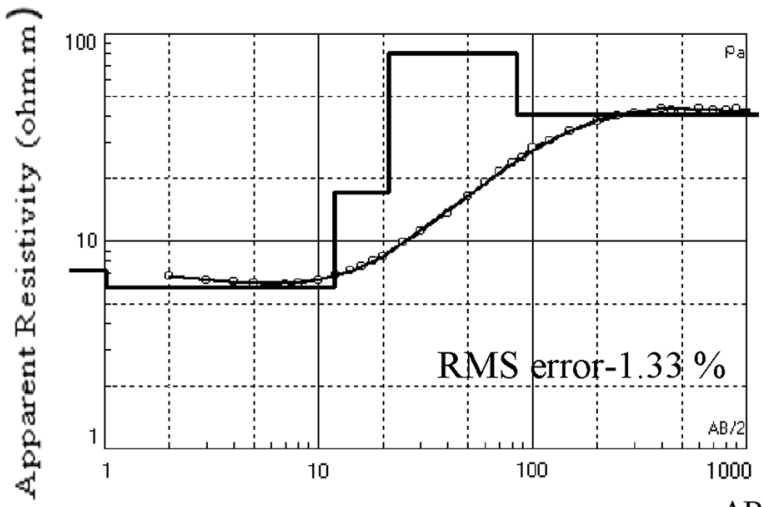

$\mathrm{AB} / 2(\mathrm{~m})$

(b)

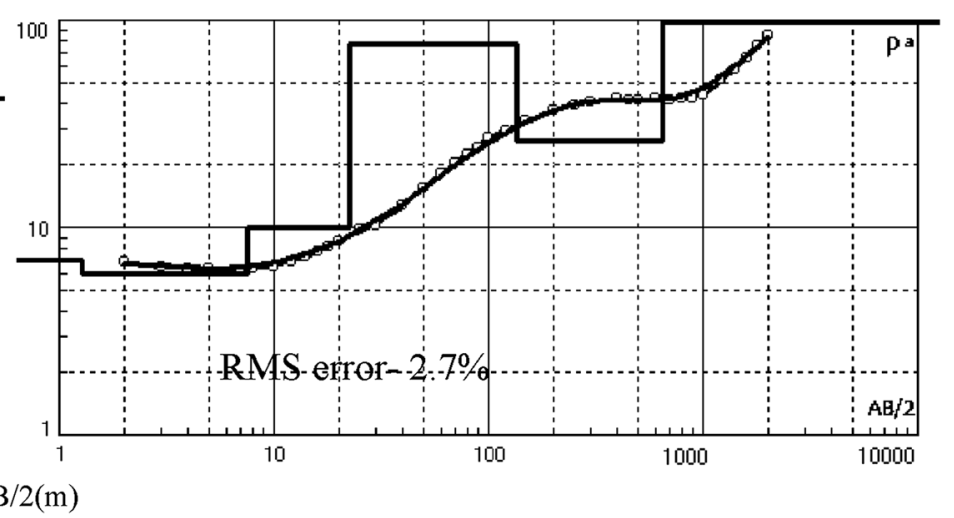

Fig. 7 VES-06 curves: (a) actual and (b) modified

Table 5 Layer Parameters of field and generated curve of VES-05

\begin{tabular}{|c|c|c|c|c|c|c|c|c|c|c|c|c|}
\hline \multirow[t]{2}{*}{ VES } & \multicolumn{2}{|c|}{ 1st Layer } & \multicolumn{2}{|c|}{ 2nd Layer } & \multicolumn{2}{|c|}{ 3rd Layer } & \multicolumn{2}{|c|}{ 4th Layer } & \multicolumn{2}{|c|}{ 5th Layer } & \multicolumn{2}{|c|}{ 6th Layer } \\
\hline & $\rho_{1}$ & $h_{1}$ & $\rho_{2}$ & $h_{2}$ & $\rho_{3}$ & $h_{3}$ & $\rho_{4}$ & $h_{4}$ & $\rho_{5}$ & $h_{5}$ & $\rho_{6}$ & $h_{6}$ \\
\hline VES-06 & 7.0 & 1.2 & 6 & 10.0 & 15 & 10.3 & 80 & 65 & 41 & - & - & - \\
\hline VES-06 modified & 7.1 & 1.2 & 5.8 & 7.7 & 10.0 & 15.0 & 76 & 112 & 26 & 512. & 7,133 & - \\
\hline
\end{tabular}

$\rho_{i}$ Resistivity values in $\Omega \mathrm{m}, h_{i}$ thickness in $\mathrm{m}$

below the coarse sand bed at Oriyara (VES-7). However, the northern extension of this clay bed from Oriyara to Sripatpur could not be identified through VES interpretation. Probably it is the case of thin layer suppression, a wellknown limitation of resistivity interpretation. Sahu et al. (2010) delineated northerly dipping clay (12- to 15-m thick) bed, having $\sim 30 \mathrm{~km}$ stretch, exposed at older alluvium areas in the south at Bhojpur District (Fig. 1d) and occurring at $\sim 100-\mathrm{m}$ depth near Ganga River. The aquifer occurring above the clay bed is referred to as a Holocene aquifer and that occurring below this clay bed is referred to as a Pleistocene aquifer. Following the same analogy, the clay bed occurring at Oriyara is extended up to Sripatpur. The course sand bed extending from Sripatpur to Gopalpur Mathai, which forms the shallow aquifer, represents the paleo channel of Sone River and sediments are probably derived from Precambrian rocks exposed further south of the study area. The paleo channel deposit formed by coarse sand is marked as newer alluvium of Holocene age. Deeper aquifer occurs below this clay bed, comprising fine to medium sand; and the aquifer is laterally extensive and is marked as Pleistocene age. The deeper aquifer gets thinner (42 $\mathrm{m}$ at Mai) toward south.

Massive bedrock is encountered at 156-m depth at the extreme south (Mai) of the section and has a northerly dip; it is encountered at a depth of $249 \mathrm{~m}$ at Dhanarua, $28 \mathrm{~km}$ north from Mai. Further north, it could not be detected within electrode spacing range. Bedrock has a dip $<0.2^{\circ}$ as calculated from the VES results.

A comparative study of the VES curve in Fig. 6 shows that VES-13 represents a KH type of curve, while the rest of the curves further south along the traverse show a predominantly HA type of trend. A sudden change in the shape of the resistivity curve (VES-13) probably indicates some structural control. EPF crossing is the traverse somewhere between VES-14 and VES-15 according to (Sahu et al. 2010), but the exact location of EPF may be a little north, near VES-13 (Fig. 1d). A change in the shape of the VES between GopalpurMathai and Sewanat Halt may be due the fact that EPF crosses the traverse between these two places. The coarse sand bed also pinches out in between the stretch marked by VES-13 and VES-14, revealing that the older course of Sone river is controlled by the tectonic activity of the region (Sahu et al. 2010) and further south from VES-13 older alluvium of Pleistocene age is exposed.

An indirect method is attempted in the present study for estimating the variation of hydraulic parameters such as transmissivity, along the traverse.

Transverse resistance (Bhattacharya and Patra 1968; Zohdy et al. 1990) is defined as for the n-layer resistivity model: 


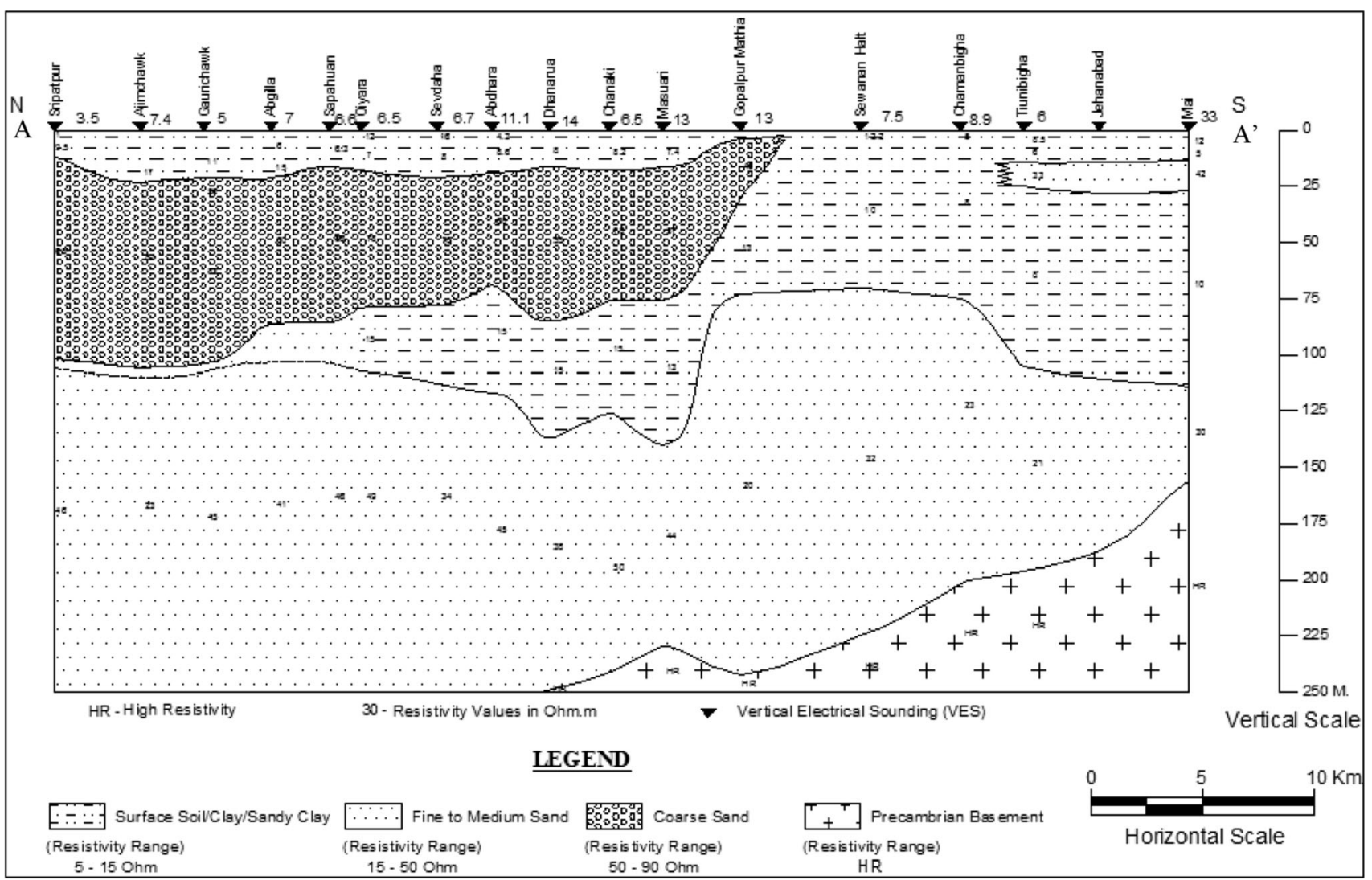

Fig. 8 Geological section derived from geoelectrical parameters along $A-A^{\prime}$ (for VES location sand traverse $A-A^{\prime}$ see Fig. 1d). The coarse sand bed forms the newer alluvium (Holocene sediments) and represents the paleo channel of the Sone River

Transverse resistance $(\mathrm{TR})=\sum_{n}^{i} \rho_{i} h_{i}$ where $\rho_{i}$ and $h_{i}$ indicate the resistivity and thickness of the ith layer, respectively.

A number of studies (Kelly 1977; Niwas and Singhal 1985) were carried out to correlate transverse resistance (TR) and transmissivity (T) and all the studies suggest that there exists ga ood degree of direct linear correlation between TR and T. However, the empirical relation derived correlating the above two parameters was area specific. Transverse resistance (TR) is calculated for all the VES for a 150-m column; since the maximum basement depth is $156 \mathrm{~m}$, a 150 -m-thick column was chosen. TR varies from 2056 to $9110 \Omega \mathrm{m}^{2}$ from south to north along the traverse and the variation is shown in Fig. 9. The figure shows an exponential decay of TR from north to south. Since TR has direct linear correlation with transmissivity $(\mathrm{T}), \mathrm{T}$ variation along the traverse will follow the trend of TR. It indicates that aquifer potential reduces (exponential decay) from newer alluvium to older alluvium, attributed to increasing thickness of clay bed at the top of the aquifer system in older alluvium areas and finer sediments of the deeper aquifer. Transmissivity value presented in Table 1 confirms the same fact.

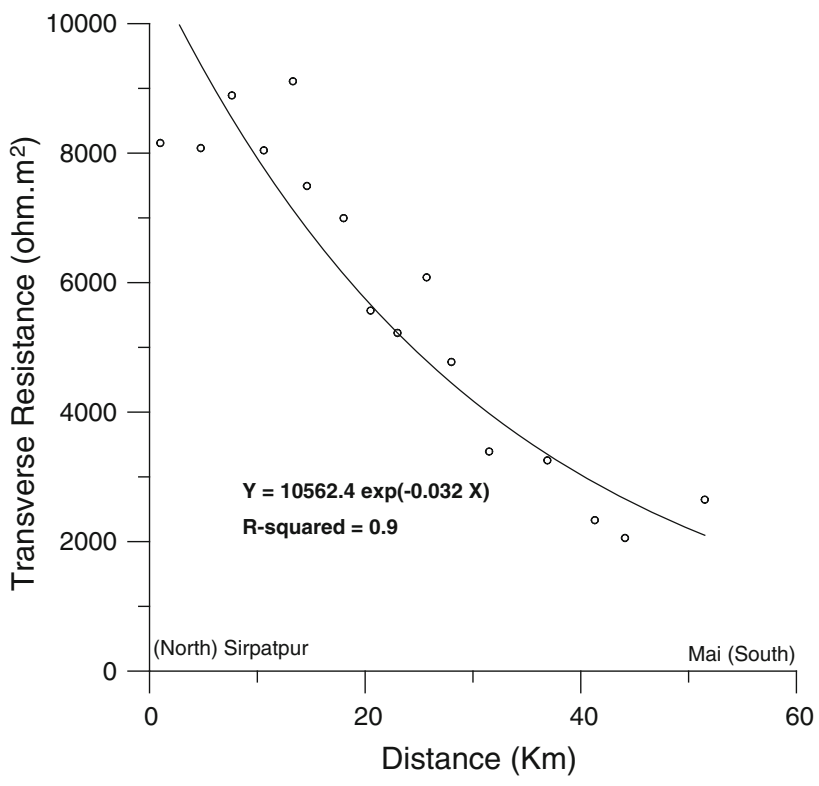

Fig. 9 Variation of transverse resistance along the geoelectrical section (see Fig. 8 for the section)

A schematic diagram, based on the above discussions, representing the aquifer system along the traverse is presented in Fig. 10. Three broad groups of lithologies are 
Fig. 10 Schematic north-south aquifer system along the geoelectrical section (Fig. 8)

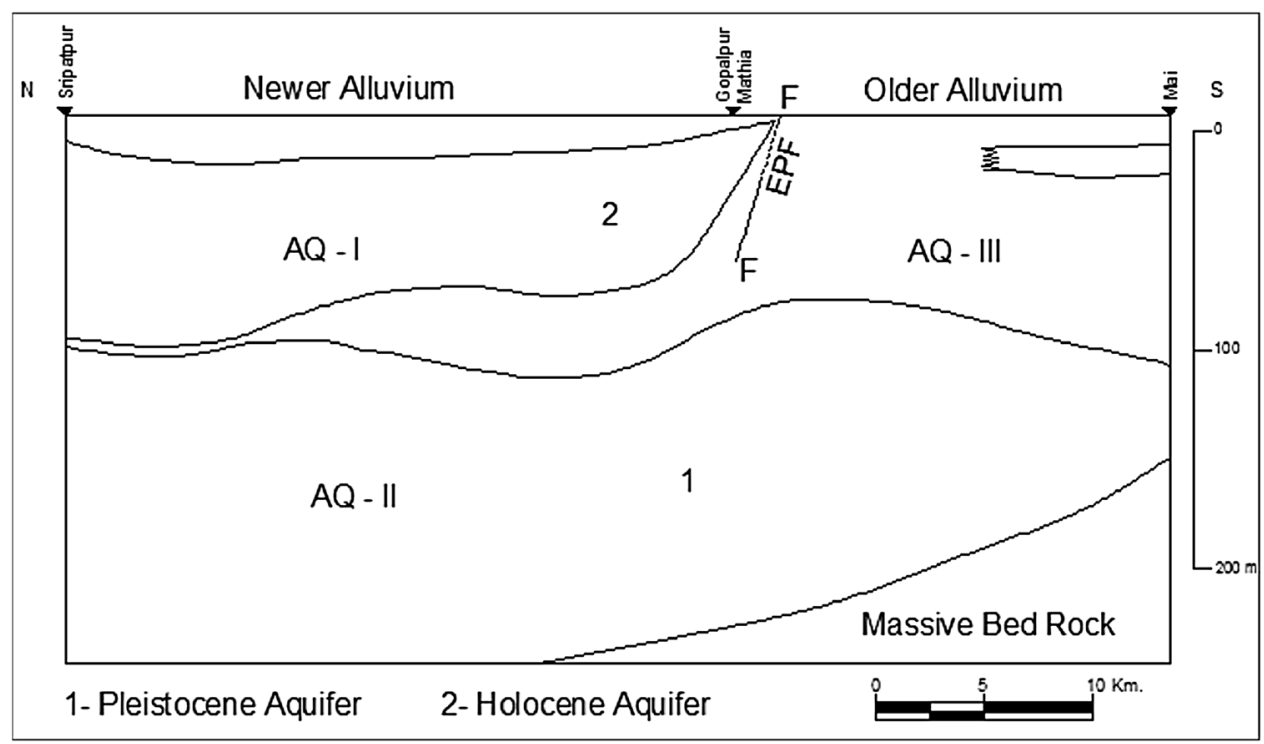

identified along the traverse: (a) coarse sand forming shallow (depth 25-105 m) potential aquifer, leveled as AQ-I; (b) fine to medium sand forming a deeper aquifer below AQ-I, continuing up to a depth of $250 \mathrm{~m}$ and leveled as AQ-II; (c) Clay/sandy clay forming an aquifer (aquitard) leveled as AQ-III.

Two-tier aquifer systems exist for the newer alluvium areas, the shallow one is AQ-I and deeper one is AQ-II, vertically separated by a clay bed of varying thickness. It can be inferred that groundwater occurs under unconfined condition, with a relatively higher transmissivity or hydraulic conductivity in AQ-I. AQ-II is laterally extensive from north to south, where groundwater occurs under semiconfined to confined condition. The overall grain size in AQ-II is finer and it can be inferred that AQ-II will have lower transmissivity.

\section{Conclusion}

1. Newer and older alluvium boundary is traced along the traverse and it is slightly south of Gopalpur Mathai. The boundary coincides with the trace of EPF along the traverse.

2. A two-tier aquifer system exists in the Newer alluvium area, and the shallow aquifer, formed by the paleo channel of Sone River, forms a potential aquifer. The two aquifer systems in the newer alluvium are replaced by a single aquifer system in the adjoining Older alluvium areas.

3. The paleo course of Sone River is traced along the geoelectrical traverse and extends from Sripatpur (north) to Gopalpur Mathai (south). It appears that the river course is controlled by the tectonic activity at Quaternary. The bedrock gently dips toward north.

4. The transverse resistance (TR) (and in terms of transmissivity) of the aquifer system up to a depth of $150 \mathrm{~m}$ shows an exponential decay from north to south.

5. Water abstraction structures, especially hand pumps in the northern part of the study area (up to Gopalpur Mathai in south) should tap the aquifer from 20 to $100 \mathrm{~m}$ for high and sustainable yield, and for the southern part of the study deep tube well in the depth range $70-150 \mathrm{~m}$ should be constructed for maximum sustainable yield.

Acknowledgments The authors express their sincere thanks to Dr P C Chandra, Regional Director (Retd), CGWB for his constructive suggestions and encouragement during the entire course of the work. Sincere thanks are extended to the anonymous reviewer for painstaking review of the manuscript.

Open Access This article is distributed under the terms of the Creative Commons Attribution License which permits any use, distribution, and reproduction in any medium, provided the original author(s) and the source are credited.

\section{References}

Acharya SK (2005) Arsenic levels in groundwater from Quaternary alluvium in Ganga Plain and the Bengal Basin, Indian subcontinent. Insights into influences of stratigraphy. Gondwana Res 8:55-66

Bhattacharya PK, Patra HP (1968) Direct current geo-electrical sounding- principle and interpretation. Elsevier, Amsterdam

Bobachev A (2003) IPI2Win-1D automativ and manual interpretation software for VES data. http://geophys.geol.msu.ru/ipi2win.htm 
Bose RN, Bose PK, Mukherjee BB (1976) A review of seismic refraction and magnetic curves in the gangetic plains of Shabad, Gaya, Patna and Munhgyr district, Bihar. Records of the Geological survey of India, Kolkata, India 10(2):73-79

CGWB, PHED (2005) A report on status of arsenic contamination in groundwater in the state of Bihar and action plan to mitigate it. Central Ground Water Board and Public Health Engineering Department, Govt of Bihar, Patna, p 35

Chakraborty C, Chattopadhyay GS (2001) Quaternary geology of south Ganga plain in Bihar. Indian Minerals 55(3\&4):133-142

Chandra S, Ahmed S, Nagaiaha E, Singh SK, Chandra PC (2011) Geophysical exploration for lithological control of arsenic contamination in groundwater in Middle Ganga Plains, India. Phys Chem Earth 36(16):1353-1362

Flathe H (1967) Interpretation of geoelectrical resistivity measurements for solving hydrogeological problems: mining and ground water Geophysics/1967. Geol. Survey of Canada, Econ Geol Report 26:52-61

Govt of Bihar (1994) Report of second Bihar State irrigation commission, vol 2. Govt of Bihar, Patna, p 633

Govt of Bihar (2001) Minor Irrigation Census (2000-2001). Govt of Bihar, Patna

Govt of India (2001) Population census report of Bihar. Govt of India, New Delhi

Govt of India (2006) Dynamic ground water resources of India. Ministry of water resources, New Delhi

Kelly WE (1977) Geoelectric sounding for estimating aquifer hydraulic conductivity. Ground Water 15(6):420-425

Niwas S, Singhal DC (1985) Estimation of aquifer transmissivity from Dar Zarrouk Parameters in porous Media. J Hydrology 50:393-399

Parasnis DS (1997) Principle of Applied Geophysics, 7th edn. Chapman and Hall, London

Raja J, Israili SH, Raja MA, Sekhar A (2003) Groundwater Resource development in Jamui district Bihar, India. Hydrogeology J $11: 396-400$

Rao MBR (1973) The subsurface geology of the Indo-Gangetic plains. J Geol Soc India 14:17-242

Saha D, Upadhyaya S, Dhar YR, Singh RS (2007) The aquifer system and evaluation of its hydraulic parameters in parts of South Ganga Plain, Bihar. J Geol Soc India 52:279-286
Saha D, Dhar YR, Vittala SS (2009a) Delineation of groundwater development potential zones in parts of marginal Ganga alluvial plain in South Bihar, Eastern India. Environ Monit Assess 165:179-191

Saha D, Sreehari SMS, Dwivedi SN, Bhartariya KG (2009b) Evaluation of hydrogeochemical processes in arsenic contaminated alluvial aquifers in parts of Mid-Ganga Basin. Environ Earth Sci, Bihar. doi:10.1007/s12665-009-0392-y

Saha D, Sahu S, Chandra PC (2010) Arsenic-safe alternate aquifers and their hydraulic characteristics in contaminated areas of Middle Ganga Plain, Eastern India. Environ Monit Assess. doi:10.1007/s10661-010-1535-z

Sahu $\mathrm{S}$ et al (2010) Active tectonics and geomorphology in the SoneGanga alluvial tract in mid-Ganga Basin, India. Quatern Int. doi:10.1016/j.quaint.2010.05.023

Sastri VV, Bhandari LL, Raju ATR, Dutta AK (1971) Tectonic framework and subsurface stratigraphy of the Gangetic basin. J Geol Soc India 12:223-233

Singh IB (2004) Late quaternary history of the Ganga Plain. J Geol Soc India 64:431-454

Sinha R, Tandon SK, Gibling MR, Bhattacharjee PS, Dasgupta AS (2005) Late Quaternary geology and alluvial stratigraphy of the Ganga basin. Himalayan Geol 26(1):223-240

Tandon SK, Sinha R, Gibling MR, Dasgupta AS, Ghazanfari P (2008). Late quaternary evolution of the Ganga Plains: myths and misconceptions, recent developments and future directions. Geol Soc India Memoir: 1-41

Telford WM, Geldart LP, Sheriff RE (1990) Applied Geophysics, 2nd edn. Cambridge University Press, Cambridge

Yadav GS, Singh SK (2007) Integrated Resistivity Surveys for Delineation of Fractures for Ground Water Exploration in Hard Rock Areas. J Appl Geophys 62(3):301-312

Zohdy AAR, Jacson DB (1969) Application of deep electrical soundings for ground water exploration in Hawaii. Geophysics 34:584-600

Zohdy AAR, Eaton GP, Mabey DR (1990) Application of surface geophysics to ground water exploration, USGS open file report 